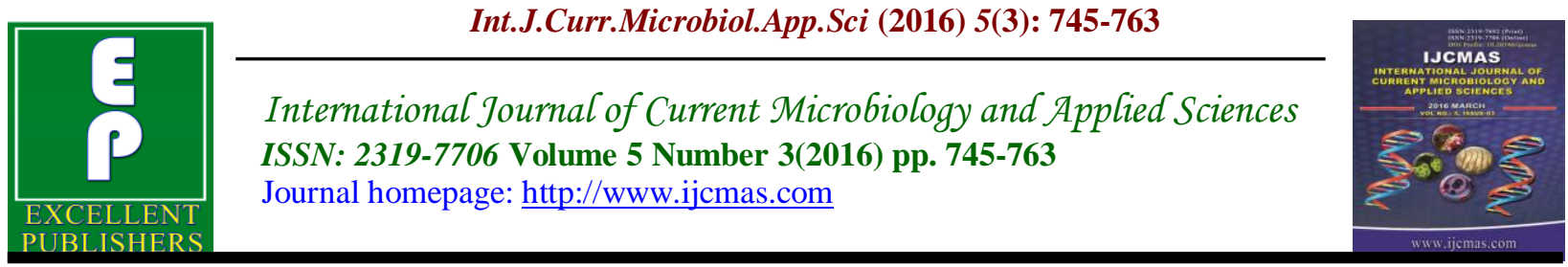

Original Research Article

http://dx.doi.org/10.20546/ijcmas.2016.503.087

\title{
Screening, Identification, Characterization and Production of Bacterial Lipase from Oil Spilled Soil
}

\author{
Mahima Golani*, Krishnan Hajela and G. P. Pandey \\ School of Life Sciences, Devi Ahilya University, Indore (M.P.), India \\ *Corresponding author
}

Keywords

Lipase, Screening, Staphylococcus chromogenes $\mathrm{O1A}$, Characterization, Production, Oil spilled soil.

Article Info

Accepted:

20 February 2016

Available Online:

10 March 2016

\section{A B S T R A C T}

A bacterial strain isolated from oil spilled soil and identified as Staphylococcus chromogenes O1A by morphological, cultural, biochemical tests and 16S rDNA gene sequence analysis with maximum lipase activity (3.1) was screened on tributyrin medium. Maximum lipase production was observed at $48 \mathrm{~h}$ of growth $(2.30 \mu \mathrm{M} / \mathrm{min} / \mathrm{mg}), 37^{\circ} \mathrm{C}$ temperature $(2.30 \mu \mathrm{M} / \mathrm{min} / \mathrm{mg})$ and $\mathrm{pH} 7.0$ (7.96 $\mu \mathrm{M} / \mathrm{min} / \mathrm{mg})$ with agitation of $130 \mathrm{rpm}(3.02 \mu \mathrm{M} / \mathrm{min} / \mathrm{mg})$. Yeast extract $(2.07$ $\mu \mathrm{M} / \mathrm{min} / \mathrm{mg}$ ) was found to be the best nitrogen source (1\%). Lactose was used as a non Lipidic carbon source (1\%) for optimum production of lipase (1.69 $\mu \mathrm{M} / \mathrm{min} / \mathrm{mg}$ ). Of the natural oils, Sunflower oil was able to induce more lipase $(3.87 \mu \mathrm{M} / \mathrm{min} / \mathrm{mg})$. Among the metal ions tested $\mathrm{Ca}^{2+}$ enhanced the lipase activity $(1.67 \mu \mathrm{M} / \mathrm{min} / \mathrm{mg})$ and $\mathrm{Zn}^{2+}$ showed lower activity $(0.28 \mu \mathrm{M} / \mathrm{min} / \mathrm{mg})$. The enzyme was found to be stable in $0.5 \%$ solutions of different Surfactants such as SDS, Triton X-100 \& Tween80. On the basis of optimized parameters the lipase activity in newly designed production medium 3 was found to be higher (18.18 $\mu \mathrm{M} / \mathrm{min} / \mathrm{mg}$ ).

\section{Introduction}

The demand for microbial industrial enzymes has attracted much interest owing to their novel \& multifold applications in a wide variety of processes. Lipases are triacylglycerol hydrolases (EC 3.1.1.3) that catalyze the hydrolysis of triacylglycerol to glycerol and fatty acids (Sharma et al., 2001).

Currently bacterial lipases are of great demand because of potential industrial applications (Sirisha et al., 2010). Lipases find their applications in various industrial sectors like processing of fats and oils, detergents and degreasing formulations, food processing, chemical and pharmaceuticals, paper mills, etc (Rubin and Dennis, 1997a,b; Kazlauskas and Bornscheuer, 1998; Masse et al., 2001; Takamoto et al., 2001).

The most suitable sources for lipase production are microbes including bacteria, fungi and yeast. These microorganisms can produce high quality lipases at lower cost and shorter time (Trichel et al., 2010). Cost of lipase enzyme (food/ feed/ industrial grade) is US \$ $10-30 / \mathrm{kg} \& 200$ tons/ month is its requirement in daily life. 
Bacterial lipases are glycoproteins but some extracellular bacterial lipases are lipoproteins. Among bacteria, Achromobacter sp., Alcaligenes sp., Arthrobacter sp., Pseudomonas sp., Staphylococcus sp. and Chromobacterium sp. (Godfredson et al., 1990) have been exploited for the production of lipases. Staphylococcal lipases are lipoprotein in nature (Brune et al., 1992). Many Staphylococci are able to produce extracellular lipases and some of them have been purified and their biochemical properties studied in detail (Oort et al., 1989; Gotz et al., 1985; Farrell et al., 1993; Lee and Iandolo, 1986; Talon et al., 1996; Oh et al., 1999; Simons et al., 1996; Jaeger et al., 1999; Van-Kampen et al., 2001; Pandey et al., 1999).

In order to get the highest yields of lipase, the optimal growth conditions were studied (Linefield et al., 1990). Bacterial lipases are mostly extracellular and are greatly influenced by nutritional and physicochemical factors, such as temperature, $\mathrm{pH}$, nitrogen and carbon sources, presence of lipids, inorganic salts, agitation and dissolved oxygen concentration (Brune and Gotz, 1992; Aires-Barros et al., 1994; Jaeger et al., 1994; Kim et al., 1996).

Various methods of lipase assay have been classified as; Titrimetry, Interfacial tensiometry, Spectroscopy, Chromatography, Immunochemistry and Conductimetry (Beisson et al., 2000; Kulkarni, 2002) of these methods titrimetry is the simplest method which was used in our studies also.

The purpose of the present study was to screen potential lipase producing bacteria from various samples and optimize the production of lipase by isolated and identified strain as Staphylococcus chromogenes O1A.

\section{Materials and Methods}

\section{Screening of Lipase Producing Bacteria}

\section{Collection of Samples}

Various 17 samples from diverse sources, such as oil contaminated soils of vegetable oil processing factories, oil packing industries \& selling shops, auto garage soil, domestic waste water (sewage), slaughter house soil, spoiled coconut water, milk \& milk cream etc. were collected in and around the city of Indore of Madhya Pradesh, India for the isolation of potential lipase producing bacteria.

\section{Enrichment and Isolation of Lipolytic Bacteria}

Lipolytic bacteria were screened by enrichment culture technique from 17 diverse samples. These samples were enriched by inoculating in Tributyrin broth medium flask $(50 \mathrm{ml})$ containing $0.5 \%(\mathrm{w} / \mathrm{v})$ peptone, $0.3 \%(\mathrm{w} / \mathrm{v})$ yeast extract, $1 \%(\mathrm{v} / \mathrm{v})$ Tributyrin $\mathrm{pH} 7.0$ \& 9.0 and incubated at $37^{\circ} \mathrm{C}$ for $48 \mathrm{hrs}$. After incubation, a loopful of growth obtained from each enriched culture sample was isolated on Tributyrin agar medium plates (Lawrence et al., 1967) $(\mathrm{pH} 7 \& 9)$ by sector plate method and incubated at $37^{\circ} \mathrm{C}$ for $48 \mathrm{hrs}$.

\section{Screening of the Isolates for Lipase Activity}

Lipolytic organisms were screened by qualitative plate assay. The lipolytic activity of isolated colonies were observed by spot inoculation on Tributyrin agar medium plates and incubated at $37^{\circ} \mathrm{C}$ for $48 \mathrm{hrs}(\mathrm{pH}-$ 7 \& 9) and zone of clearance was observed due to hydrolysis of tributyrin by lipase. The alkalotolerant nature of isolates was determined by growing each isolate of $\mathrm{pH}-7$ Tributyrin agar medium plate to $\mathrm{pH}-9$ 
Tributyrin agar medium plate \& vice versa and incubating at $37^{\circ} \mathrm{c}$ for $48 \mathrm{hrs}$. The organisms producing maximum zone of hydrolysis around the colony were selected for further study. Pure cultures of the isolate were maintained on minimal medium agar slants containing $0.5 \%(\mathrm{w} / \mathrm{v})$ peptone, $0.3 \%$ $(\mathrm{w} / \mathrm{v})$ yeast extract, $0.5 \%(\mathrm{w} / \mathrm{v}) \mathrm{NaCl}, 2.0 \%$ $(\mathrm{w} / \mathrm{v})$ agar $\mathrm{pH} \quad 7.0$ at refrigerated temperature and were sub cultured every month.

\section{Characterization and Identification of Selected Isolate}

The bacterial isolate, O1A ( $\mathrm{pH}-7)$ isolated from oil spilled soil from vegetable oil packing factory of Indore region of Madhya Pradesh, found to produce maximum zone of hydrolysis (Table-1) around the colony was selected and was studied for its morphological, cultural, physiological, biochemical characteristics and 16S rDNA gene sequence analysis. The colonial characteristics of the isolate were studied on Tributyrin agar medium plate $(\mathrm{pH}-7)$.

\section{Morphological Characteristics}

The size, shape and arrangement of the cells were studied by Gram's staining technique.

\section{Standard \\ Characterization}

The physiological characteristics included the growth experiments to check the effect of various parameters on growth of bacterial isolate $(\mathrm{O} 1 \mathrm{~A})$. The growth experiments at $\mathrm{pH}$ 4.4-12, growth at various $\mathrm{NaCl}$ concentrations $(0.5 \%-10 \%)$, growth at various Sucrose concentrations $(0.5 \%-10 \%)$ and at various temperatures $\left(15-55^{\circ} \mathrm{C}\right)$ were performed in Tributyrin broth medium by inoculating the inoculum (1\%) and incubated at $37^{\circ} \mathrm{C}$ for $24 \mathrm{hrs}$. The growth of the organism (O.D.) was determined spectrophotometrically at $660 \mathrm{~nm}$.

\section{Identification}

The taxonomic status of the selected bacterium O1A was identified following the criteria laid down by Bergey's Manual of Determinative Bacteriology (Holt et al., 1994). The biochemical tests such as indole production from tryptophan, methyl-red and Voges-Proskauer tests, Simmons' citrate utilization test, urea hydrolysis, production of $\mathrm{H}_{2} \mathrm{~S}$ from cysteine, various sugar fermentation tests, catalase and oxidase activity, Nitrate reduction tests were examined.

The isolate was further identified up to species level and confirmed on the basis of $1500 \mathrm{bp}$ of $16 \mathrm{~S}$ rDNA gene sequence analysis by Merck Millipore, Bangalore, India.

\section{Molecular Characterization and Identification of the Bacteria \\ DNA Preparation and PCR Amplification}

Genomic DNA was isolated from the culture using DNA Extraction Solution, Cat No. 612104680501730. Using consensus primers, 16S rDNA fragment was amplified using Taq DNA Polymerase. Primers used for PCR amplification were the Forward primer 5'-AGAGTTTGATCMTGGCT CAG-3' and Reverse primer 5'-ACGGYTA CCTTGTTACG ACTT-3'. Amplification process was carried out in $50 \mu 1$ of reaction mixture containing 20 ng Genomic DNA, $1.0 \mu 1$ dNTP mix (2.5mM each), 100ng Forward Primer, 100ng Reverse Primer, 1X Taq Buffer A (10X), 3U Taq Polymerase enzyme and glass distilled water to make up the volume $50 \mu \mathrm{l}$. Thermal cycler was programmed as denaturation at $94^{\circ} \mathrm{C}$ for 5 
min followed by subsequent 35 cycles of denaturation at $94^{\circ} \mathrm{C}$ for $30 \mathrm{sec}$, annealing at $55^{\circ} \mathrm{C}$ for $30 \mathrm{sec}$, extension at $72^{\circ} \mathrm{C}$ for $2 \mathrm{~min}$ with final extension at $72^{\circ} \mathrm{C}$ for $5 \mathrm{~min}$. The PCR product was analyzed on $1.0 \%$ agarose gel along with Step Up ${ }^{\mathrm{TM}} 500 \mathrm{bp}$ DNA ladder.

\section{S rDNA Sequencing and Data Analysis}

Sequencing analysis was performed on a 1500 bp by PCR product. The PCR product was cloned into TA vector and sequenced using The $\mathrm{T} 7$ forward read, 13BG read (internal primer) \& SP6 (reverse primer) and were checked for the overlap to get the similarity and then compile the whole sequence with results obtained. This compiled sequence uploaded in NCBI Basic Local Alignment Search Tool BLAST with nucleotide filtering option to get the 10 closest homologs. A distance matrix was generated using the Kimura-2-Parameters. The phylogenetic analysis was performed using CLUSTAL W program (Thompson et al., 1997) and multiple sequence alignment. The phylogenetic trees made using Neighbour Joining method (Saitou and Nei, 1987) with alphabet size 4 and length size 1000 .

\section{Characterization of the Isolate O1A for Lipase Activity}

The isolate $(\mathrm{O} 1 \mathrm{~A})$ showing the maximum zone of clearance was selected for further analysis. The extracellular lipase produced by $\mathrm{O} 1 \mathrm{~A}$ a soil isolate was characterized for optimum temperature, optimum $\mathrm{pH}$, and various carbon and nitrogen sources.

\section{Lipase Assay}

The selected bacterium (O1A) was assayed for extracellular lipase production using titrimetric method using olive oil as a substrate. Olive oil $(10 \% \quad \mathrm{v} / \mathrm{v})$ was emulsified with gum Arabic (5\% w/v) in $0.1 \mathrm{M}$ Tris-HCl buffer with $\mathrm{pH}$ 7.0. 0.1 $\mathrm{ml}$ of cellular extract/partially purified lipase was added to the emulsion and incubated for $30 \mathrm{~min}$. at $37^{\circ} \mathrm{C}$. The reaction was stopped and fatty acids were extracted by addition of $2.0 \mathrm{ml}$ of acetone. The amount of fatty acid liberated was estimated by titrating with $0.05 \mathrm{M} \mathrm{NaOH}$ until $\mathrm{pH} 10.5$ using phenophathelin as indicator. Amount of $\mathrm{NaOH}$ required to achieve end point (colorless to pink) was recorded (Jensen, 1983). One unit of lipase activity is defined as the amount of enzyme required to hydrolyse $\mu \mathrm{mol}$ of fatty acids from triglycerides.

\section{Lipase Activity}

$(\mu \mathrm{M} / \mathrm{min} / \mathrm{ml})=$

Volume of alkali consumed $\times$ Strength of alkali $\times 1000$

Volume of sample $\times$ Time in min

One unit (U) of lipase activity is equal to one $\mu \mathrm{mol}$ of free fatty acid liberated per min per $\mathrm{ml}$ using the assay condition.

Specific activity was determined as enzyme unit per mg of total protein concentration. Protein concentration was determined by Lowry's method (Lowry et al., 1951).

Enzyme Unit $(\mu \mathrm{M} / \mathrm{min})=$ Fatty Acids Liberated $(\mu \mathrm{M}) /$ Time of Incubation (in min)

Specific Activity ( $\mu$ M.min-1.mg-1) = Enzyme Units / Protein Concentration

\section{Optimization of Media Parameters for Lipase Production by Isolate Ola}

\section{Influence of Incubation Period on Lipase Activity}

To study the effect of time course of lipase production, 500-ml Erlenmeyer flasks each containing $100 \mathrm{ml}$ of Tributyrin broth medium containing yeast extract, $\mathrm{NaCl}$, Peptone and $1 \%(\mathrm{w} / \mathrm{v})$ olive oil was 
inoculated with $1 \%$ of inoculum and incubated at $37^{\circ} \mathrm{C}$ in orbital shaker at a rotary speed of $130 \mathrm{rpm}$ for 5 days (120 hours). The crude broth was harvested, aseptically, at every 12 hours interval by high speed cooling centrifugation at 10,000 $\mathrm{g}$ for $30 \mathrm{~min}$ at $4^{\circ} \mathrm{C}$. The supernatant collected was used as crude enzyme solution and was assayed for enzyme activity.

\section{Influence of Temperature on Lipase Activity}

For selecting optimum temperature for lipase production by isolate $\mathrm{O} 1 \mathrm{~A}$, the incubation temperatures varying from $22^{\circ} \mathrm{C}$ - $42^{\circ} \mathrm{C}$ were selected, keeping the remaining parameters same, except the incubation period as standardized above.

\section{Influence of pH on Lipase Activity}

Effect of $\mathrm{pH}$ on lipase action was analyzed by substituting the buffer in reaction mixture with the different buffers for different $\mathrm{pH}$. Acetate buffer for $\mathrm{pH}-4,5$; Phosphate buffer for $\mathrm{pH}-6,7,8$; \& $\mathrm{pH}-9,10$ was adjusted by adding $\mathrm{Na}_{2} \mathrm{CO}_{3}$. Thus $\mathrm{pH}$ from 4.0 to 10.0 was scanned for determining the optimal $\mathrm{pH}$ for lipase production by the isolate $\mathrm{O} 1 \mathrm{~A}$, keeping other parameters unchanged except for the incubation time and temperature, as optimized.

\section{Influence of Agitation Speed on Lipase Activity}

To determine the optimum agitation speed for the maximum production of lipase by isolate $\mathrm{O} 1 \mathrm{~A}$, the isolate was cultured in orbital shaking incubator at varying rotary speed from $110-160 \mathrm{rpm}$ at $37^{\circ} \mathrm{C}$ for $48 \mathrm{hrs}$.

\section{Influence of Different Lipidic Carbon Sources (Oils) on Lipase Activity}

To evaluate different Lipidic C-sources for maximum lipase production by the isolate
O1A, olive oil $(1 \% \mathrm{w} / \mathrm{v})$ present in the culture media was replaced with different oils like palm oil, sunflower oil, mustard oil, soybean oil, coconut oil, groundnut oil, castor oil, tributyrin and ghee, with the respective final concentration of $1 \%(\mathrm{w} / \mathrm{v})$. The other parameters were as per their respective optimized value.

Influence of Different Non Lipidic Carbon Sources (Sugars) on Lipase Activity

Effect of Non Lipidic Carbon sources on the lipase production was analysed with different Carbon sources glucose, mannose, xylose, mannitol, fructose, lactose, sucrose, maltose, molasses at a concentration of $1 \%$ $(\mathrm{w} / \mathrm{v})$ were added into the production medium on a rotary shaker $(130 \mathrm{rpm})$ and incubated at $37^{\circ} \mathrm{C}$ for $48 \mathrm{hrs}$ and the enzyme was assayed.

\section{Influence of Different Nitrogen Sources on Lipase Activity}

Different organic nitrogen sources like peptone, yeast extract, beef extract, gelatin, casein, soy meal, corn steep liquor, tryptose and inorganic nitrogen sources like ammonium sulphate, ammonium hydrogen phosphate, urea, and sodium nitrate were added to the broth at a final concentration of $1 \%$ (w/v). Remaining parameters were unaltered.

\section{Influence of Different Concentration of Oil on Lipase Activity}

To study the effect of different concentration of olive oil, the culture media flasks with different percentage of oil $1,3,6,9,12,15$ $\%$ were inoculated with $1 \%$ of inoculum and incubated at $37^{\circ} \mathrm{C}$ for $48 \mathrm{hrs}$ in a rotary shaker $(130 \mathrm{rpm})$ and the enzyme was assayed. 
Influence of Different mineral salts on Lipase Activity

Screening for the optimum mineral salts was conducted using the lipase production medium containing either of the mineral salts viz., magnesium sulphate $\left(\mathrm{MgSO}_{4}\right)$, manganese sulphate $\left(\mathrm{MnSO}_{4}\right)$, copper sulphate $\left(\mathrm{CuSO}_{4}\right)$, zinc sulphate $\left(\mathrm{ZnSO}_{4}\right)$, iron sulphate $\left(\mathrm{FeSO}_{4}\right)$, calcium chloride $\left(\mathrm{CaCl}_{2}\right)$, calcium carbonate $\left(\mathrm{CaCO}_{3}\right)$ at a concentration of $0.02 \%$ were inoculated with $1 \%$ of inoculum and incubated at $37^{\circ} \mathrm{C}$ for $48 \mathrm{hrs}$ in a rotary shaker (130 rpm) and the enzyme was assayed.

\section{Influence of Surfactants on Lipase Activity}

Various surfactants viz., Tween 80 , and Triton X-100 (0.5\%, v/v); SDS $(0.5 \%, \mathrm{w} / \mathrm{v})$ were incorporated in the production medium. Rest of the parameters was kept unaltered and checked for lipase assay.

\section{Design of Production Media for maximum yield of Lipase Activity}

On the basis of optimization of media parameters for Lipase production by Isolate $\mathrm{O} 1 \mathrm{~A}$, various media were designed to get the maximum yield of lipase enzyme activity.

Composition of Fermentation Media (gram/100ml) are, Medium 1: Sun flower Oil-2 ml; Yeast Extract-1gm; $\mathrm{NaCl}-0.5 \mathrm{gm} ; \quad$ Lactose-1gm; $\quad \mathrm{MnSO}_{4-}$ $0.02 \mathrm{gm} ; \mathrm{K}_{2} \mathrm{HPO}_{4}-1.07 \mathrm{gm} ; \mathrm{KH}_{2} \mathrm{PO}_{4}-0.52 \mathrm{gm}$; $\mathrm{D} / \mathrm{W}-100 \mathrm{ml} ; \mathrm{pH}-7.0$ (Phosphate buffer). Medium 2: Olive Oil-2 ml; Yeast Extract-0.3gm; NaCl-0.5gm; Peptone$0.5 \mathrm{gm} ; \mathrm{D} / \mathrm{W}-100 \mathrm{ml} ; \mathrm{pH}-7.0$. Medium 3: Sun flower Oil-1 ml; Yeast Extract$0.3 \mathrm{gm} ; \mathrm{NaCl}-0.5 \mathrm{gm} ; \quad$ Peptone-0.5gm; Lactose-1gm; $\quad \mathrm{CaCl}_{2}-0.02 \mathrm{gm} ; \quad \mathrm{K}_{2} \mathrm{HPO}_{4}-$ $1.07 \mathrm{gm} ; \mathrm{KH}_{2} \mathrm{PO}_{4}-0.52 \mathrm{gm}$; Tween80- $0.5 \mathrm{ml}$;
D/W-100 ml; pH-7.0 (Phosphate buffer). Medium 4: Sun flower Oil-1 ml; Yeast Extract-0.3gm; NaCl-0.5gm; Peptone$0.5 \mathrm{gm} ; \quad$ Lactose-1gm; $\quad \mathrm{CaCl}_{2}-0.05 \mathrm{gm}$; $\mathrm{K}_{2} \mathrm{HPO}_{4}-1.07 \mathrm{gm} ; \quad \mathrm{KH}_{2} \mathrm{PO}_{4}-0.52 \mathrm{gm}$; Tween80- 1ml; D/W-100 ml; $\quad$ pH-7.0 (Phosphate buffer).

These media were inoculated with $1 \%$ of inoculum in 500-ml Erlenmeyer flasks each containing $100 \mathrm{ml}$ of medium and incubated at $37^{\circ} \mathrm{C}$ in orbital shaker at a rotary speed of $130 \mathrm{rpm}$ for 48 hours. The crude broth was harvested, aseptically, by high speed cooling centrifugation at $10,000 \mathrm{~g}$ for 30 min at $4^{\circ} \mathrm{C}$. The supernatant collected was used as crude enzyme solution and was assayed for enzyme activity.

\section{Results and Discussion}

\section{Screening of Lipase Producing Bacteria}

\section{Enrichment, Isolation and Screening of Lipolytic Bacteria}

72 Lipolytic bacterial isolates were screened by enrichment culture technique from 17 diverse samples. Out of these 24 isolates were found to be growing well at $\mathrm{pH} 7 \& 9$. Among the 24 Isolates, $\mathrm{O} 1 \mathrm{~A}(\mathrm{pH}-7)$ showed maximum zone of hydrolysis around colony (Fig-1) and was also able to grow at pH-9 with maximum lipase activity (3.12) (Table1) which shows its alkali tolerant nature and was selected for further studies.

\section{Characterization of Selected Bacterial Isolate}

\section{Morphological and Cultural Characterization of Selected Isolate}

The morphological and cultural studies of selected isolate O1A were performed. The isolate O1A was found to be gram positive cocci. The colonial characters of isolate 
O1A were medium, round, even, regular, low convex, smooth, opaque, orange pigmented.

\section{Physiological and Biochemical Characterization}

Isolate designated as O1A was studied further for their physiological characters. The isolate $\mathrm{O} 1 \mathrm{~A}$ was able to grow up to $\mathrm{pH}$ 9.2 which shows its alkali tolerant nature. Optimum temperature for growth was $37^{\circ} \mathrm{C}$ and was able to tolerate up to $7.5 \%$ salt and $5 \%$ sucrose concentration. It was negative towards citrate utilization, indole test, MRVP tests, $\mathrm{H}_{2} \mathrm{~S}$ production, urea hydolysis and oxidase. The strain could reduce nitrate weakly and was catalase positive.

\section{Molecular Characterization and Identification of the Bacteria}

The strain showing maximum zone of hydrolysis was designated as O1A. Using consensus primers, the $\sim 1.5 \mathrm{~kb} 16 \mathrm{~S}$ rDNA fragment was amplified using Taq DNA Polymerase by PCR technique (Fig-2). The physiological analysis of this strain using its $16 \mathrm{~S}$ rDNA sequence shows that strain O1A had highest homology (99.9\%) with Staphylococcus sp. ChDC B592 (accession no. KF733731.1). The biochemical characteristics as well as phylogenetic trees made using Neighbour Joining method (Saitou and Nei, 1987) suggested that the isolate O1A was close to Staphylococcus chromogenes (Hajek et al., 1987) which was earlier named as Stapylococcus hyicus subsp. Chromogenes (Devriese et al., 1978). Hence this strain was identified as Staphylococcus chromogenes O1A.

\section{Optimization of Media Parameters for Lipase Production by Staphylococcus chromogenes 01A}

Influence of Incubation Period on Lipase

\section{Activity}

The effect of incubation time on lipase production revealed that maximum lipase production $2.30 \mu \mathrm{M} / \mathrm{min} / \mathrm{mg}$ for Staphylococcus chromogenes O1A was found to be at 48 hours of incubation. The activity gradually decreased after 48 hours (Fig-3).

\section{Influence of Temperature and $\mathrm{pH}$ on Lipase Activity}

The Study of the effect for the optimization of temperature on lipase production showed that the bacteria produce lipase in wide range of temperature from $22^{\circ} \mathrm{C}$ to $42^{\circ} \mathrm{C}$. The optimum temperature for lipase enzyme production was at $37^{\circ} \mathrm{C}(2.30 \mu \mathrm{M} / \mathrm{min} / \mathrm{mg})$ (Fig-4) and the enzyme production was affected and decreased after increase of temperature above $37^{\circ} \mathrm{C}$ to $42{ }^{\circ} \mathrm{C}$. It was also noted that the lipase enzyme production was ceased at temperature $22^{\circ} \mathrm{C}$.

It was observed from the results that the bacterium is capable of producing lipase from initial $\mathrm{pH} 4.0$ to $\mathrm{pH} 10.0$. The enzyme production varied considerably from 0.181 to $7.96 \mu \mathrm{M} / \mathrm{min} / \mathrm{mg}$. The bacteria Staphylococcus chromogenes $\mathrm{O} 1 \mathrm{~A}$ has optimum lipase production at $\mathrm{pH} 7.0$ (7.96 $\mu \mathrm{M} / \mathrm{min} / \mathrm{mg}$ ) (Fig-5). However it was noted that the lipase production was declined with increase in $\mathrm{pH}$ from $\mathrm{pH} 7.0$ to $\mathrm{pH} 10.0$ but was able to produce lipase towards alkaline $\mathrm{pH}$ which shows its alkalotolerant nature.

\section{Influence of Agitation Speed on Lipase Activity}

Agitation at $110 \mathrm{rpm}$ to $130 \mathrm{rpm}$ enhanced the lipase production. The optimum agitation speed for the production of lipase by the bacteria was $130 \mathrm{rpm} \quad(3.02$ 
$\mu \mathrm{M} / \mathrm{min} / \mathrm{mg}$ ). The rate of agitation speed above $130 \mathrm{rpm}$ led to decrease in the enzyme production ((Fig-6).

Influence of Lipidic (Oils) and Non Lipidic Carbon Sources (Sugars) on Lipase Activity

It was inferred from the results that the maximum lipase production of the natural oils, sunflower oil was able to induce more lipase (3.87 $\mu \mathrm{M} / \mathrm{min} / \mathrm{mg})$ followed by mustard oil and olive oil while optimizing the process for Lipidic C-source (Fig-7).

Among the Non Lipidic C-sources, it was reported that $1 \%$ lactose was the best carbon source for lipase production (1.69 $\mu \mathrm{M} / \mathrm{min} / \mathrm{mg}$ ) followed by moloasses (1.488 $\mu \mathrm{M} / \mathrm{min} / \mathrm{mg}$ ) by Staphylococcus chromogenes O1A (Fig-8).

\section{Influence of Different Nitrogen Sources} on Lipase Activity

Among the different organic nitrogen sources, yeast extract $(2.07 \mu \mathrm{M} / \mathrm{min} / \mathrm{mg})$ enhanced lipase production followed by beef extract $\quad(1.83 \mu \mathrm{M} / \mathrm{min} / \mathrm{mg}) \quad$ by Staphylococcus chromogenes O1A while inorganic nitrogen sources were found to be poor for lipase production (Fig-9).

\section{Influence of Different Concentration of Oil on Lipase Activity}

Production of lipase by Staphylococcus chromogenes $\mathrm{O} 1 \mathrm{~A}$ gradually increased from $1 \%-12 \%$ and was found to be maximum at $12 \%$ olive oil concentration (2.50 $\mu \mathrm{M} / \mathrm{min} / \mathrm{mg}$ ) in the production medium while it got reduced at $15 \%$ of olive oil concentration $(0.8 \mu \mathrm{M} / \mathrm{min} / \mathrm{mg})$ (Fig-10). But $1-2 \%$ of oil was sufficient to induce lipase production.
Influence of Different mineral salts on Lipase Activity

Among the metal ions tested $\mathrm{Ca}^{2+}$ enhanced the lipase activity $(1.67 \mu \mathrm{M} / \mathrm{min} / \mathrm{mg})$ followed by $\mathrm{Mn}^{2+}(0.92 \mu \mathrm{M} / \mathrm{min} / \mathrm{mg}) \& \mathrm{Zn}^{2+}$ showed lower activity $(0.28 \mu \mathrm{M} / \mathrm{min} / \mathrm{mg})$, while $\mathrm{Mg}^{2+}, \mathrm{Cu}^{2+} \& \mathrm{Fe}^{2+}$ inhibited its activity (Fig-11).

\section{Influence of Surfactants on Lipase Activity}

In order to determine the effect of surfactant at a conc. of $0.5 \%$ in production medium, SDS $(2.27 \mu \mathrm{M} / \mathrm{min} / \mathrm{mg})$ was shown to enhance lipase production after $48 \mathrm{hrs}$ of incubation which was followed by Triton X$100(2.0 \mu \mathrm{M} / \mathrm{min} / \mathrm{mg})$ \& Tween80 (1.72 $\mu \mathrm{M} / \mathrm{min} / \mathrm{mg}$ ) (Fig-12).

\section{Lipase Activity in designed production medium of isolate $\mathrm{O1A}$}

The specific lipase activity of isolate $\mathrm{O} 1 \mathrm{~A}$ in designed production medium 1 was found to be $(3.55 \mu \mathrm{M} / \mathrm{min} / \mathrm{mg})$, in medium 2 (11.89 $\mu \mathrm{M} / \mathrm{min} / \mathrm{mg})$, and medium 3 (18.18 $\mu \mathrm{M} / \mathrm{min} / \mathrm{mg})$, medium $4(5.52 \mu \mathrm{M} / \mathrm{min} / \mathrm{mg})$ (Fig-13). Results indicates that medium 3 was found to increase the lipase activity maximally which was used further for production and purification of lipase enzyme.

Bacterial lipases are mostly extracellular and are greatly influenced by the type and concentration of carbon and nitrogen sources, the culture $\mathrm{pH}$, the growth temperature, and the dissolved oxygen concentration (Elibol and Ozer, 2001). Many strains of staphylococci have been reported previously which produce extracellular lipases e.g. Staphylococcus aureus, S. caseolyticus, S. epidermidis, S. haemolyticus, S. hyicus, S. warneri, S. 
xylosus (Jaeger et al., 1999; Volpato et al., 2008; Simons et al., 1998; Oh et al., 1999; Van Kampen et al., 1998; Khoramnia et al., 2010).

Staphylococcus chromogenes O1A, the isolate reported in this study, also produces extracellular lipase in $48 \mathrm{hrs}$. The results are in good accordance with Kumar et al., 2012. Maximum lipase activity was observed at $37^{\circ} \mathrm{C}$ temperature and $\mathrm{pH} 7.0$ by Staphylococcus chromogenes O1A. Similar results were reported for staphylococcus sp. (Sirisha et al., 2010). Various Pseudomonas species were found to be mesophilic (Dharmasthiti and Kuhasuntisuk, 1998, Dong et al. 1999; Kulkarni and Gadre, 1999, Rashid et al., 2001, Kanwar et al., 2002).
This finding supports the data by Veerapagu et al., 2013 that the optimum temperature for lipase enzyme production by Pseudomonas gessardii was also at $37^{\circ} \mathrm{C}$.

Most bacterial species are able to produce greater amounts of lipase at $\mathrm{pH} 6.5$ to 7.0 (Dharmsthiti et al., 1998; Gao et al., 2004; Joseph et al., 2006). S. xylosus lipase remained active at a $\mathrm{pH}$ range of 6-10 (Khoramnia et al., 2010). The bacteria Pseudomonas gessardii has optimum lipase production at $\mathrm{pH} 7.0$ (Veerapagu et al., 2013). Our results were found to be similar accordingly that is $\mathrm{pH} 7.0$ adjusted by phosphate buffer during lipase production by Staphylococcus chromogenes O1A.

Table \# 1

COMPARATIVE ANALYSIS OF LIPASE ACTIVITY BY ISOLATES (PH-7.O)

\begin{tabular}{|c|c|c|c|c|}
\hline $\begin{array}{l}\text { S. } \\
\text { No. }\end{array}$ & $\begin{array}{l}\text { Designation of } \\
\text { Isolates }\end{array}$ & $\begin{array}{l}\text { Zone of lipid hydrolysis } \\
\text { (mm) }\end{array}$ & $\begin{array}{l}\text { Growth zone } \\
(\mathrm{mm})\end{array}$ & $\begin{array}{l}\text { Lipolytic } \\
\text { activity * }\end{array}$ \\
\hline 1 & O1A & 25 & 8 & 3.12 \\
\hline 2 & O7A & 21 & 11 & 1.90 \\
\hline 3 & O8A & 20 & 10 & 2.00 \\
\hline 4 & $013 \mathrm{~A}$ & 19 & 10 & 1.90 \\
\hline 5 & O1B & 18 & 8 & 2.25 \\
\hline 6 & G4A & 20 & 8 & 2.50 \\
\hline 7 & G5A & 21 & 12 & 1.75 \\
\hline 8 & S3A & 15 & 7 & 2.14 \\
\hline 9 & OC & 15 & 8 & 1.87 \\
\hline 10 & C1 & 19 & 10 & 1.90 \\
\hline 11 & St1 & 18 & 10 & 1.80 \\
\hline 12 & $\mathrm{St} 2$ & 19 & 10 & 1.90 \\
\hline
\end{tabular}

* Lipolytic activity = Hydrolysis zone $(\mathrm{mm})$ : growth zone $(\mathrm{mm})$ 

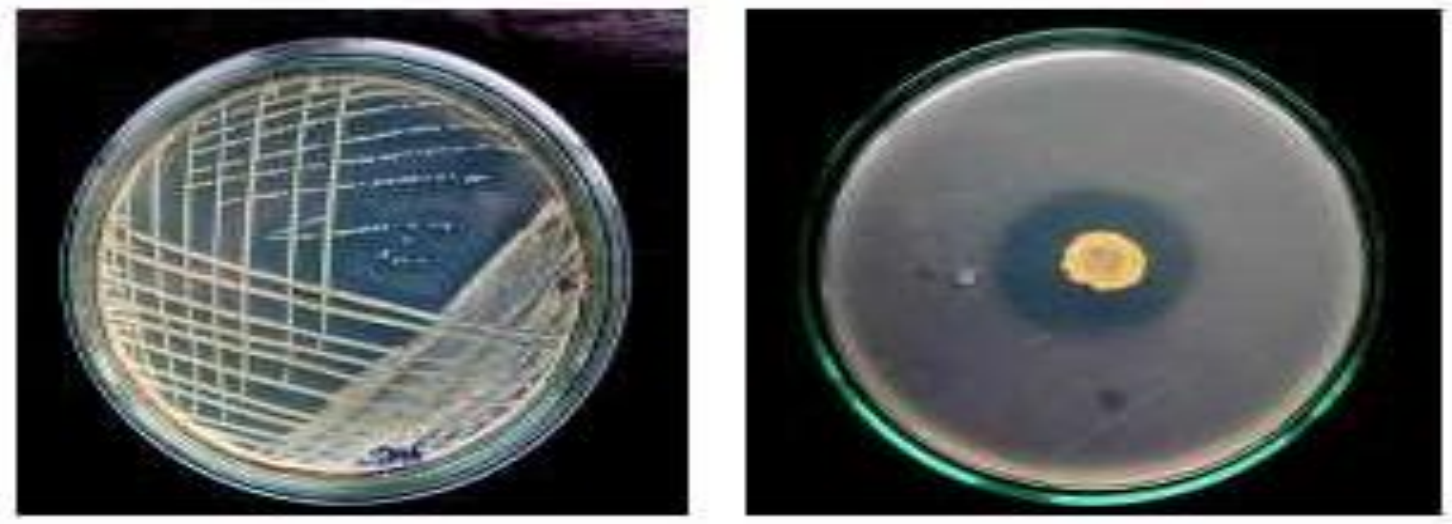

Fig.1 Zone of hydrolysis by lipase producing Staphylococus chromogenes O1A on Tributyrin agar plate

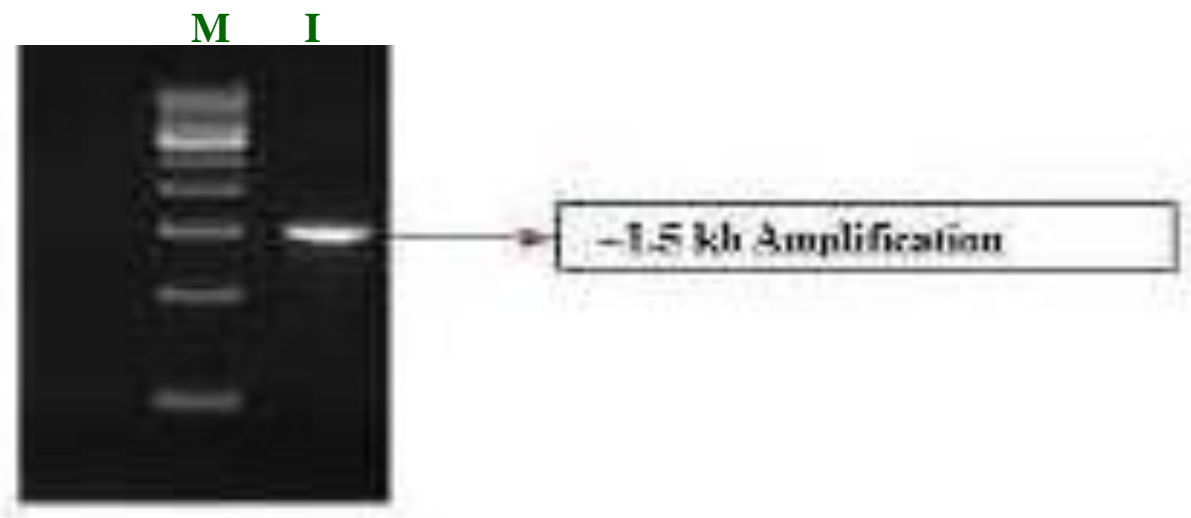

Fig.2 Lane Description

Lane-1 PCR Amplification of - Staphylococcus chromogram O1 A Lane-2 StepUpTM 500bp DNA ladder (Cx\#612657970501730)

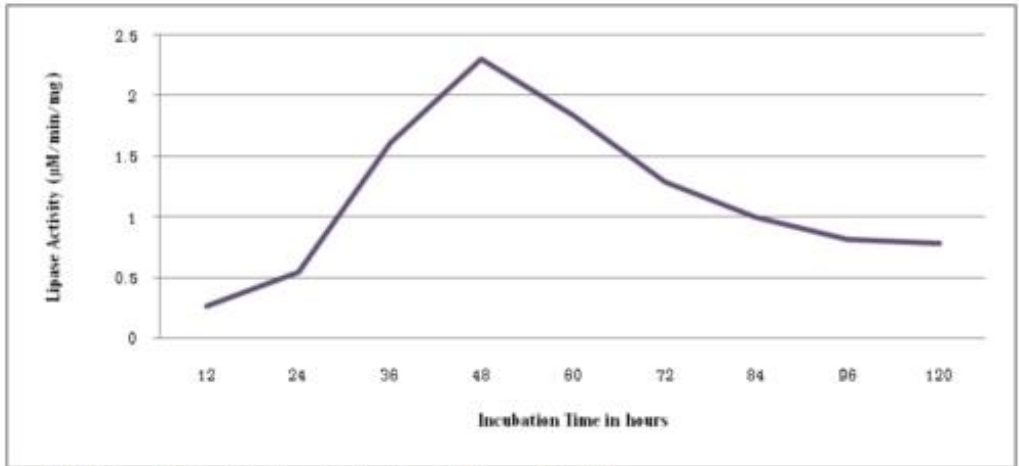

Fig- 3: Effect of Incubation Period on Lipase Activity 
Int.J.Curr.Microbiol.App.Sci (2016) 5(3): 745-763

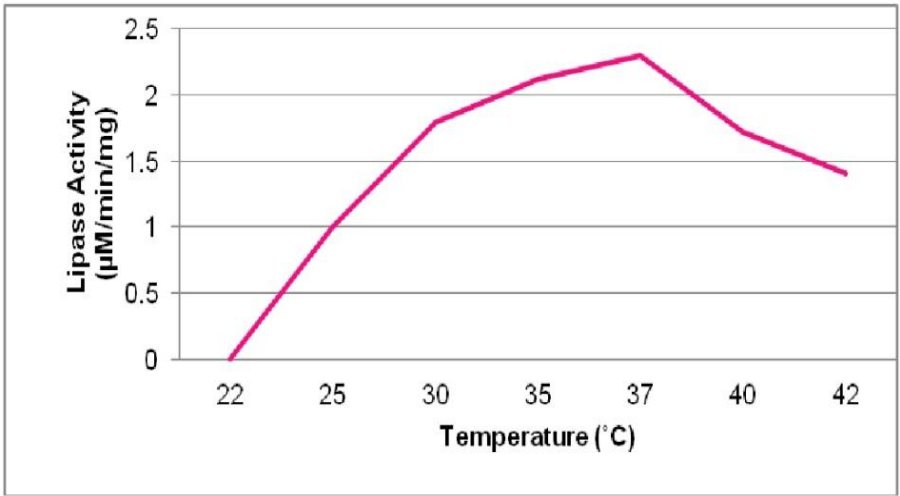

Fig- 4: Effect of Temperature on lipase Activity

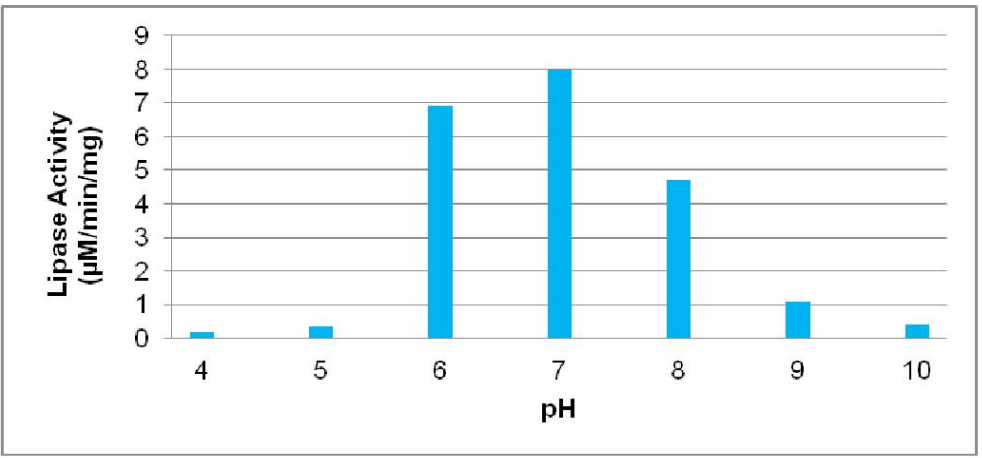

Fig- 5: Effect of pH on Lipase Activity

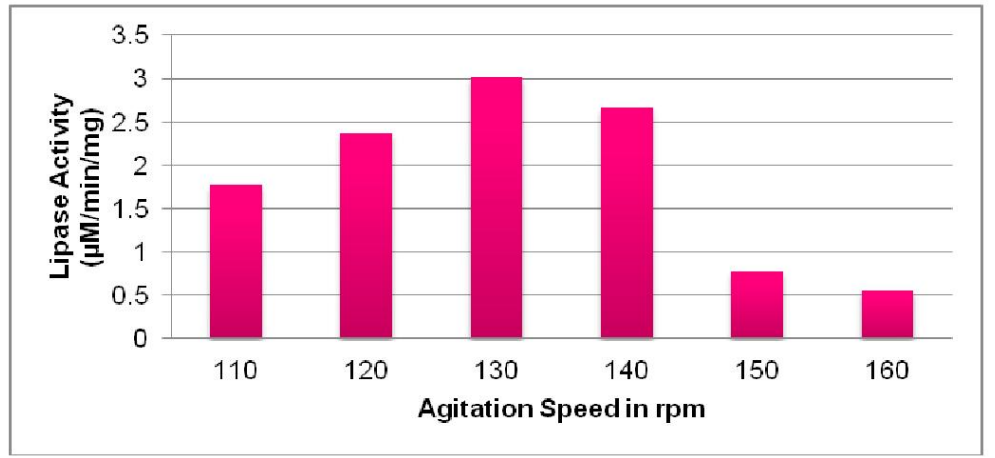

Fig- 6: Effect of Agitation Speed on Lipase Activity 


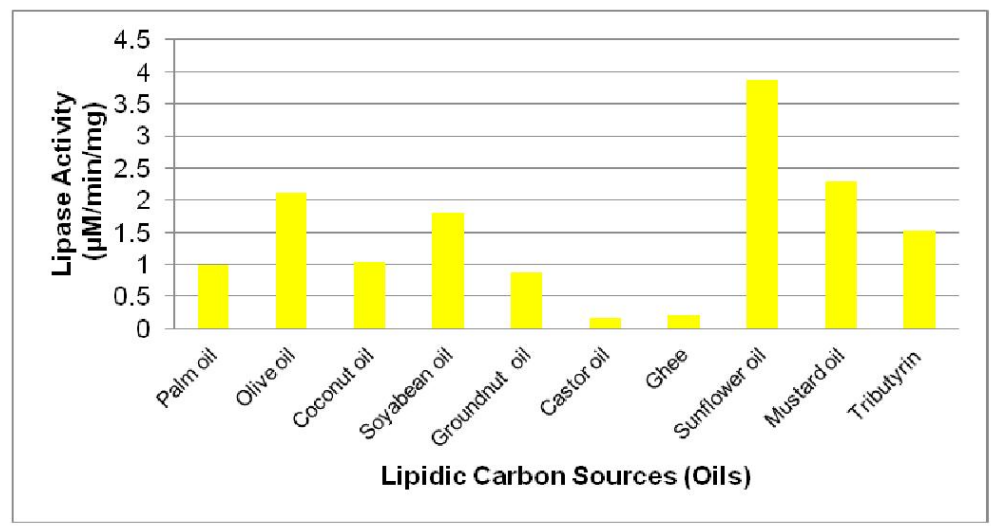

Fig- 7: Effect of Lipidic carbon Sources on lipase Activity

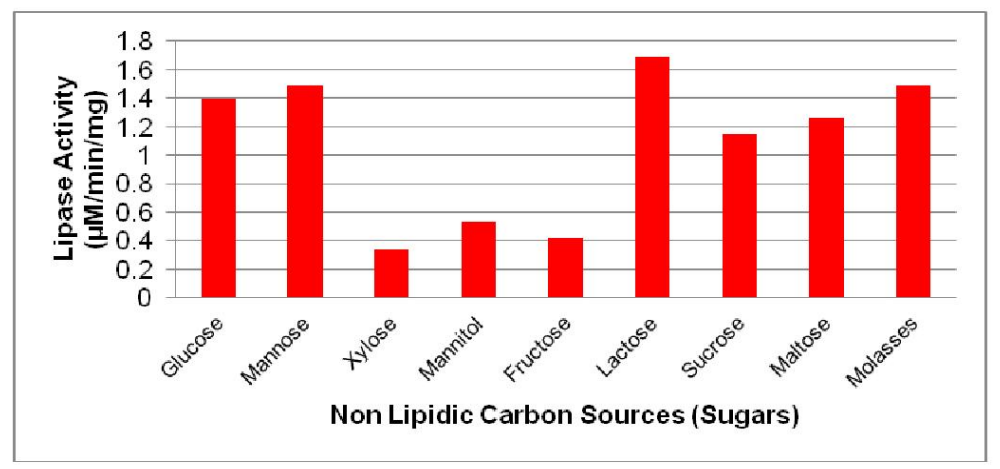

Fig- 8: Effect of Non Lipidic carbon Sources on lipase Activity

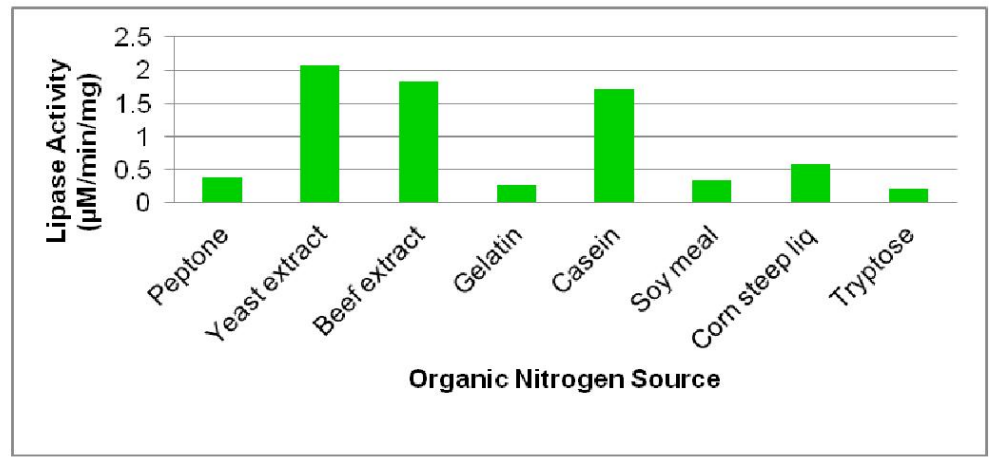

Fig- 9: Effect of Organic Nitrogen Sources on lipase Activity 
Int.J.Curr.Microbiol.App.Sci (2016) 5(3): 745-763

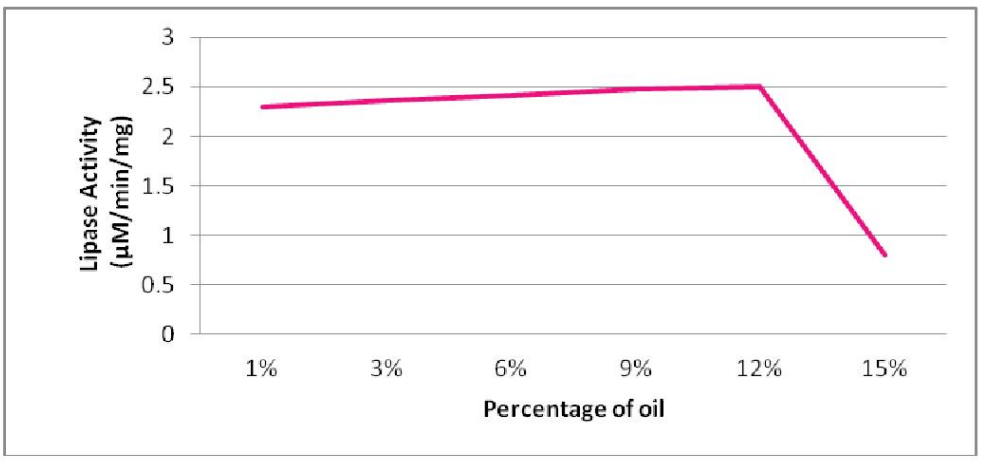

Fig- 10: Effect of Different Concentration of Oil on lipase Activity

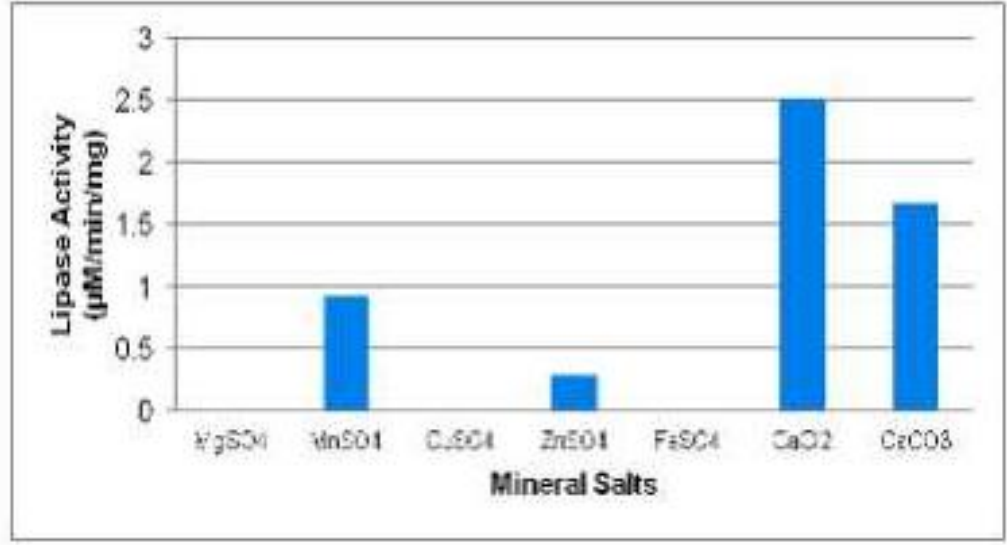

Fig- 11: Effect of Mineral Salts on lipase Activity

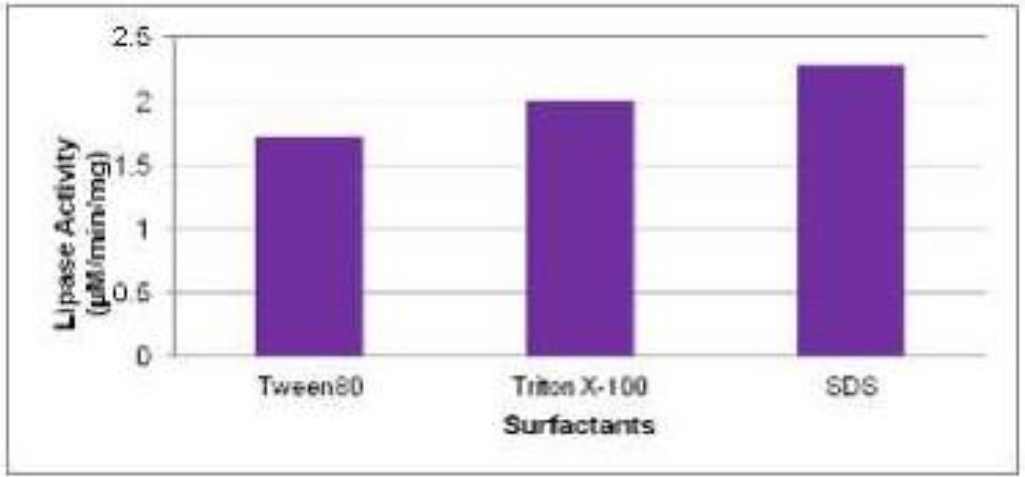

Fig12: Effect of Different Surfactants on lipase Activity 


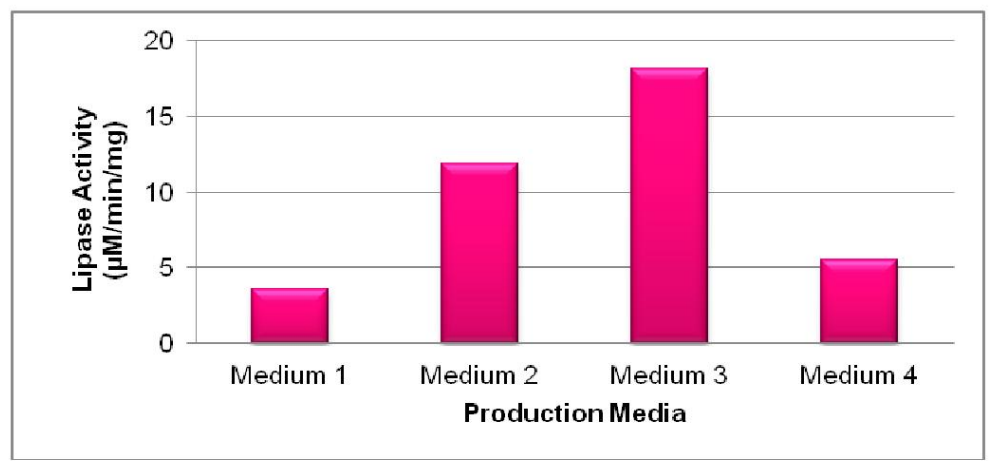

Fig- 13: Effect of Different Production Media on lipase Activity

It was clear from the results that agitation is required for proper mixing of oil and medium along with bacterial culture for the production of lipase (Veerapagu et al., 2013).

Lipidic C-source that is sunflower oil (1\%) induced more lipase production by Staphylococcus chromogenes O1A than Non Lipidic C-sources (1 \% lactose). Lipidic carbon sources seem to be generally essential for obtaining a high lipase yield. Most bacterial lipases are generally induced in medium that contains the proper fatty acids and oils (Joseph et al., 2006; Immanuel et al., 2008; Kiran et al., 2008). Other carbon sources such as sugars, polysaccharides, whey, casamino acids and other complex sources influences its production significantly (Dharmsthiti and Kuhasuntisuk 1998; Ghanem et al. 2000; Rashid et al. 2001). Natural oil like palm oil was found to be best carbon source for Staphylococcus sp. (Sirisha et al., 2010) and mustard oil for Pseudomonas sp. (Tembhurkar et al., 2012). Among the different carbon sources used, olive oil was found to be the most suitable carbon source (Senthilkumar et al., 2008, Omar et al., 2010, Mishra et al., 2011, Kumar et al., 2012).

Besides carbon source, the type of nitrogen source in the medium also influences the lipase titers in production broth (Ghosh et al., 1996). Staphylococcus chromogenes O1A released maximum lipase when organic nitrogen sources like Yeast Extract and Peptone were used in the production medium 3 and poor yield with inorganic nitrogen sources. Generally, microorganisms provide high yields of lipase when organic nitrogen sources are used, such as peptone and yeast extract, which have been used for lipase production by various thermophilic Bacillus sp. (viz. B. alcalophilus, Bacillus sp. RSJ1) (Ghanem et al., 2000, Sharma et al., 2002b), and $P$. aeruginosa KKA-5 (Sharon et al., 1998) and by Staphylococcus xylosus also (Khormania et al., 2010). In some cases meat extract and yeast extract was found to be the best carbon source for Staphylococcus spp (Tembhurkar et al., 2012, Kumar et al., 2012). Sharon et al., (1998) reported a lipase of $P$. aeruginosa KKA-5 that retained its activity in presence of $\mathrm{Ca}^{2+}$ and $\mathrm{Mg}^{2+}$ but was slightly inhibited by $\mathrm{Mn}^{2+}, \mathrm{Cd}^{2+}$, and $\mathrm{Cu}^{2+}$. In our results $\mathrm{Ca}^{2+}$ enhanced the lipase activity of Staphylococcus chromogenes $\mathrm{O} 1 \mathrm{~A}$ while $\mathrm{Mg}^{2+}, \mathrm{Cu}^{2+} \& \mathrm{Fe}^{2+}$ inhibited its activity. The effect of various metal ions on $S$. epidermidis lipase activity was reported that enzyme needed calcium as a cofactor for catalytic activity (Simons et al., 1998). Metal 
cations, particularly $\mathrm{Ca}^{2+}$, play important roles in influencing the structure and function of enzymes, and calciumstimulated lipases have been reported (Khattabi et al., 2003). It has been demonstrated that the activity of Staphylococcal lipases may depend on the presence of $\mathrm{Ca}^{2+}$ ions (Rosenstein and Gotz, 2000). The lipase activity of S. xylosus increased maximum about 3 times at the $\mathrm{Ca}^{2+}$ concentration of $10 \mathrm{mM}$ however, Mosbah et al., (2005) reported 1.9 times increase with $2 \mathrm{mM} \mathrm{Ca}^{2+}$ concentration. It has been reported that the lipases from Staphylococcus hyicus (Rosenstein and Gotz, 2000; Tiesinga et al., 2007) contain a $\mathrm{Ca}^{2+}$-binding site which is formed by two conserved aspartic acid residues near the active-site, and that binding of the $\mathrm{Ca}^{2+}$ ion to this site dramatically enhanced the activities of these enzymes. These data supports our results that $\mathrm{Ca}^{2+}$ ions enhance lipase activity.

Among the different lipase inducers tested, Tween 80 produced a great level of extracellular lipase (Anbu et al. 2011). The same results were observed when Tween 80 $(0.5 \%)$ was used in production medium 3 during the lipase production by Staphylococcus chromogenes O1A.

The isolate O1A, characterized as Staphylococcus chromogenes O1A, has shown a broad range of $\mathrm{pH}$ (6-10) and temperature $\left(25-42^{\circ} \mathrm{C}\right)$. The newly designed production medium 3 increased the yield of lipase enzyme. It can be used as a potential bacterial source of lipase and due to alkali tolerant nature of bacterium; lipase enzyme can be used in detergent formulation and also in various industrial applications.

\section{Acknowledgement}

The financial assistance provided by
University Grant Commission Bhopal (CRO) and facilities provided by the college and School of Life Sciences, UTD, DAVV, Indore is great fully acknowledged.

\section{References}

Aires-Barros, M.R., Taipa, M.A., Cabral, J.M.S. 1994. Isolation and purification of lipases. In: Wooley $\mathrm{P}$, Petersen SB (eds) Lipases-their structure, biochemistry and application. Cambridge University Press, Cambridge, pp. 243-270.

Anbu, P., Noh, M.J., Kim, D., Seo, J., Hur, B.K., Min, K.H. 2011. Screening and optimization of extracellular lipases by Acinetobacter species isolated from oil-contaminated soil in South Korea. Afri. J. Biotechnol., Vol. 10(20), pp. 4147-4156.

Beisson, F., Tiss, A., Rivie`re, C., Verger, R. 2000. Methods for lipase detection and assay: a critical review. Eur. J. Lipid Sci. Technol., 102: 133-153.

Bisht, S.P.S., Kumari, A., Panda, K.A. 2011. Isolation and identification of new lipolytic thermophilic bacteria from an Indian hot spring. Int. J. Pharm. Bio. Sci., ISSN 0975-6299 vol2/issue2.

Brune, A.K., Gotz, F. 1992. In Microbial Degradation of Natural Products (ed. Winkelmann G), VCH, Weinheim, pp. 243-263.

Dharmsthiti, S., Kuhasuntisook, B. 1998. Lipase from Pseudomonas aeruginosa LP 602: Biochemical properties and application for wastewater treatment. J. Ind. Microbiol. Biotechnol., 21: 7580.

Dharmsthiti, S., Pratuangdejkul, J., Theeragool, G., Luchai, S. 1998. Lipase activity and gene cloning of Acinetobacter calcoaceticus LP009. J. Gen. Appl. Microbiol., 44: 139-145. 
Dong, H., Gao, S., Han, S., Cao, S. 1999. Purification and characterization of a Pseudomonas sp. lipase and its properties in non-aqueous media. Appl. Microbiol. Biotechnol., 30: 251-256.

Elibol, M., Ozer, D. 2000. Influence of OxygenTransfer on Lipase Production by Rhizopus arrhizus. Process Biochem., 36: 325-329.

Farrell, A.M., Foster, T.J., Holland, K.T. 1993. Molecular analysis and expression of the lipase of Staphylococcus epiderimidis. J. Gen.Microbiol., 139: 267-277.

Gao, L., Xu, J.H., Li, X.J., Liu, Z.Z. 2004. Optimization of Serratia marcescens lipase production for enantioselective hydrolysis of 3-phenylglycidic acid ester. J. Ind. Microbiol. Biotechnol., 31: 525-530.

Ghanem, Essam H., Al-Sayed Hashim, A., Saleh Kareema, M. 2000. An alkalophilic thermostable lipase produced by a new isolate of Bacillus alcalophilus. World J. Microbiol. Biotechnol., 16: 459-464.

Ghosh, P.K, Saxena, R.K., Gupta, R., Yadav, R.P., Davidson, W.S. 1996. Microbial lipases: production and applications. Sci. Prog., 79: 119-157.

Godfredson, S.E. 1990. In Microbial Enzymes and Biotechnology (eds Fogarty WM and Kelly ET), Elsevier. Appl. Sci., The Netherlands, pp. 255273.

Gotz, F., Popp, F., Korn, E., Schleifer, K.H. 1985.Complete nucleotide sequence of the lipase from Sraphylococcus hyicus cloned in Staphylococcus carnosus. Nucleic Acids Res., 13: 5895-5906.

Hajek, V., Devriese, L.A., Mordarski, M., Goodfellow, M., Pulverer, G., Varaldo, P.E. 1986. Elevation of Staphylococcus hyicus subsp.
Chromogenes (Devriese et al. 1978) to species status: Staphylococcus Chromogenes (Devriese et al. 1978) comb. nov. Syst. Appl. Microbiol., 8: 169-173.

Holt, J.G., Krieg, N.R., Sneath, P.H.A., Staley, J.T., Williams, S.T. 1994. Bergey's Manual of Determinative Bacteriology, Ninth Edition, Williams and Wilkins, Baltimore. Group 17, Gram-Positive Cocci, 527-558.

Immanuel, G., Esakkiraj, P., Jebadhas, A., Iyapparaj, P., Palavesam, A. 2008. Investigation of lipase production by milk isolate Serratia rudidaea. Food Technol. Biotechnol., Vol.46, No.1, pp. 60-65.

Jaeger, K.E., Dijkstra, B.W., Reetz, M.T. 1999. Bacterial biocatalysts: molecular biology, three-dimensional structures and biotechnological applications of lipases. Ann. Rev. Microbiol., 53: 315-351.

Jaeger, K.E., Ransac, S., Dijkstra, B.W., Colson, C., Heuvel, M., Van Misset, O. 1994. Bacterial lipases. FEMS Microbiol. Rev., 15: 29-63.

Jensen, R.G. 1983. Detection and determination of lipase (acylglycerpl hydrolase) activity from various sources. Lipids, 18: 650-657.

Joseph, B., Ramteke, P.W., Kumar, P.A. 2006. Studies on the enhanced production of extracellular lipase by Staphylococcus epidermidis. J. Gen. Appl. Microbiol., 52: 315-320.

Kanwar, L., Gogoi, B.K., Goswami, P. 2002. Production of a Pseudomonas lipase in n-alkane substrate and its isolation using an improved ammonium sulfate precipitation technique. Bioresour. Technol., 84: 207-211.

Kazlauskas, R.J., Bornscheuer, U.T. 1998. Biotransformation with lipases. Biotechnology,New York. $V C H ., 8$ : 
37-192.

Khattabi, M.E., Van, G.P., Bitter, W., Tommassen, J. 2003. Role of the calcium ion and the disulfide bond in the Burkholderia glumae lipase. J. Mol. Catalysis B: Enzymatic, Vol. 22, No. 5-6, pp. 329-338.

Khoramnia, A., Lai, O.M., Ebrahimpour, A., Tanduba, C.J., Voon, T.S., Mukhlis, S. 2010. Thermostable lipase from a newly isolated Staphylococcus xylosus strain; process optimization and characterization using RSM and ANN. Microbial. Biotech. J., Vol. 13 No. 5.

Kim, S.S., Rhee, E.K., J.S. 1996. Effects of growth rate on the production of Pseudomonas fluorescens lipase during the fed-batch cultivation of Escherichia coli. Biotechnol. Prog., 12: 718-722.

Kiran, G.S., Shanmughapriya, S., Jayalakshmi, J., Selvin, J., Gandhimathi, R., Sivaramakrishnan, S., Arunkumar, M., Thangavelu, T., Natarajaseenivasan, $\quad$ K. 2008. Optimization of extracellular psychrophilic alkaline lipase produced by marine Pseudomonas sp. MSI057. Bioprocess Biosyst. Eng., 31: 483 492.

Kulkarni, N., Gadre, R.V. 2002. Production and properties of an alkaline, thermophilic lipase from Pseudomonas fluorescens NS2W. $J$. Ind. Food Microbiol., 28: 344-348.

Kumar, A., Parihar, S., Batra, N. 2012. Enrichment, isolation and optimization of lipase-producing Staphylococcus sp. from oil mill waste Oil cake. J. Experimental Sci., 38: 26-30.

Lawerence, R.C., Fryer, T.F., Reiter, B. 1967. Rapid method for the quantitative estimation of microbial lipases. Nature. 213: 1264-1265.
Lee, C.Y., Iandolo, J.J. 1986. Lysogenic conversion of Staphylococcal lipase is caused by insertion of the bacteriophage L54a genome into the lipase structural gene. J. Bacteriol., 166: 385-391.

Linefield, W.M., Barauskas, R.A., Serota, S.L., S.R.W. 1990. Stevenson, Enzymatic fat hydrolysis and synthesis. JAOCS, 61: 191-195.

Lowry, O.H., Rosebrough, N.J., Farr, N.J., Randall, R.J. 1951. Protein measurement with folin phenol reagent. J. Biological Chem., 193: 265-275.

Masse, L., Kennedy, K.J., Chou, S.P. 2001. The effect of an enzymatic pre treatment on the hydrolysis and size reduction of fat particles in slaughterhouse wastewater. J. Chem. Technol. Biotechnol., 76: 629-35. 17.

Mishra, A., Yaginik, S.K., Pranali, M., Yadav, S.K. 2011. Screening and Temperature Optimization for LipaseProducing Bacteria from Waste Contaminated Water. Asian J. Biochem. Pharma. Res., 1(1): 62-68.

Mosbah, H., Sayari, A., Mejdoub, H., Dhouib, H., Gargouri, Y.T. 2005. Biochemical and molecular characterization of Staphylococcus xylosus lipase. Biochimica et Biophysica Acta, 1723: 282-291.

Oh, B., Kim, H., Lee, J., Kang, S., Oh, T. 1999. Staphylococcus haemolyticus lipase: biochemical properties, substrate speci city and gene cloning. FEMS Microbiol. Lett., 179: 385-392.

Omar, C.I., Saad, S.B.M. 2010. Isolation Identification And Characterization Of Lipase- Producing Bacteria and Optimization Of Lipase Production. Faculty Of Agro Industry \& Natural Resources University Malaysia Kelantan, Locked Bag 36, 16100 
Pengkalan Chepa, Kota Bharu, Kelantan.

Oort, Van, M.G., Deveer, A.M., Dijkman, R., Tjeenk, M.L., De Haas Verheij, H.M. 1989. Purification and substrate specificity of Staphylococcus hyicus lipase. Biochem., 28: 9278-9285.

Pandey, A., Benjamin, S., Soccol, C.R., Nigam, P., Krieger, N., Soccol, U.T. 1999.The realm of microbial lipases in biotechnology. Biotechnol. Appl. Biochem., 29: 119-131.

Rashid, N., Shimada, Y., Ezaki, S., Atomi, H., Imanaka, T. 2001. Low temperature lipase from psychrotrophic Pseudomonas sp. Strain KB700A. Appl. Environ. Microbiol., 67: 4064-4069.

Rosenstein, R., Gotz, F. 2000. Staphylococcal lipases: Biochemical and molecular characterisation. Biochimie., 82: 1005-1014.

Rubin, B., Dennis, E.A. 1997. Lipases: Part B, Biotechnology Methods in enzymology. New York Academic Press, 284: 1-408.

Saitou, N., Nei, M. 1987. The neighbourjoining method: A new method for reconstructing phylogenetic trees. Mol. Biol. Evolution, Vol. 4: 406425.

Senthilkumar, R., Selvakumar, G. 2008. Isolation and characterization of an extracellular lipase producing Bacillus sp SS-1 from slaughterhouse soil. Advanced Biotech., pp. 24-25.

Sharma, R., Chisti, Y., Banerjee, U.C. 2001. Production, purification, characterization and application of lipases. Biotech. Adv., 19, pp. 627662.

Sharma, R., Soni, S.K., Vohra, R. M., Gupta, L.K., Gupta, J.K. 2002b. Purification and characterisation of a thermostable alkaline lipase from a new thermophilic Bacillus sp. RSJ-1. Process Biochem., 37(10): 10751084.

Sharon, C., Furugoh, S., Yamakido, T., Ogawa, H., Kato, Y. 1998. Purification and characterization of a lipase from Pseudomonas aeruginosa KKA-5 and its role in castor oil hydrolysis. J. Ind. Microbiol. Biotechnol., 20: 304-7.

Simons, J.W.F.A., Gotz, F., Egmond, M.R., Verheij, H.M. 1998. Biochemical properties of staphylococcal phospholipases. Chem. Phys. Lipids, 93: 27-37.

Sirisha, E., Rajasekar, N., Narasu, L.M. 2010. Isolation and Optimization of Lipase Producing Bacteria from Oil Contaminated Soils. Adv. Biol. Res., 45: 249-252.

Takamoto, T., Shirasaka, H., Uyama, H., Kobayashi, S. 2001. Lipase-catalyzed hydrolyticdegradation of polyurethane in organic solvent. Chem. Lett., 6: 492-3.

Talon, R., Marie-Christine, M., JeanLouis, B. 1996. Production of flavor esters by lipases of Staphylococcus warneri and Staphylococcus xylosus. Enzyme Microb. Technol., 19: 620622

Tembhurkar, V.R., Dama, L.B., Attarde, N.P., Zope, P.S. 2012. Production and characterization of extracellular lipases of Staphylococcus sp. Isolated from contaminated soil. Trends in Biotechnol. Res. Int. J., Vol.1, No.1, pp. 36-41.

Thompson, J.D., Gibson, T.J., Plewniak, F., Jeanmougin, F., Higgins, D.G. 1997. The CLUSTAL_X Windows interface: flexible strategies for multiple sequence alignment aided by quality analysis tools. Nucleic Acids Res., Vol. 25: 4876-4882. 
Trichel, H., Oliveira, D., Mazutti, M.A., Luccio, M.D., Oliveira, J.V. 2010. A review on microbial lipases production. Food Bioprocess Technol., 3: 182-196.

VanKampen, M.D., Simons, J.W., Dekker, N., Egmond, M.R., Verheij, H.M. 1998. The phospholipase activity of Staphylococcus hyicus lipase strongly depends on a single Ser to Val mutation. Chem. Phys. Lipids., 93: 39-45.
Veerapagu, M., Narayanan, S.A., Ponmurugan, K., Jeya, K.R. 2013. Screening Selection Identification Production And Optimization Of Bacterial Lipase From Oil Spilled Soil. Asian J. Pharm. Clin. Res., Vol. 6, Suppl. 3: 62-67.

Volpato, G., Rodrigues, R.C., Heck, J.X., Ayub, M.A.Z. 2008. Production of organic solvent tolerant lipase by Staphylococcus caseolyticus EX17 using raw glycerol as substrate. $J$. Chem. Technol. Biotechnol., V ol. 83, pp. 821-828.

\section{How to cite this article:}

Mahima Golani, Krishnan Hajela and Pandey, G. P. 2016. Screening, Identification, Characterization and Production of Bacterial Lipase from Oil Spilled Soil.Int.J.Curr.Microbiol.App.Sci. 5(3): 745-763. doi: http://dx.doi.org/10.20546/ijcmas.2016.503.087 